\title{
Women's Resistance in Palestinian Autobiographies from a Feminist Perspective Suad Amiry's Sharon and My Mother in Law
}

\author{
Samah A. F. Jarrad \\ ${ }^{1}$ Department of languages, Palestine Technical University- Kadoorie, Tulkarem, Palestine \\ Correspondence: Samah A. F. Jarrad, Department of languages, Palestine Technical University- Kadoorie. \\ E-mail: s.jarrad@ptuk.edu.ps
}

Received: August 11, 2020

doi:10.5539/mas.v14n10p1

\begin{abstract}
This paper aims to explore the role of Palestinian women in resisting both occupation and male dominance through keeping dairies that have acquired the quality of autobiographies and have been circulated widely. The main focus of this paper is Suad Amri's autobiography Sharon and my Mother in Law in which she tries to highlight both the feminist and the resistance aspects of her life in Ramallah eventually becoming representative of the lives of all women in Palestine. The research concludes that the identity of the colonized is shaped by their collective memory which is affected by their resistance narrative. The results also show that through their writing, Palestinian women have managed to reclaim their creative space and to challenge the limitations imposed on them by both occupation and patriarchy.
\end{abstract}

Keywords: collective memory, female perspective, identity, post-colonial, resistance

\section{Introduction}

Because the written word is the "memory for the forgetfulness" and because the word is mightier than the sword in sustaining the identity of the victimized ingroup, writing about injustice has always been vital in keeping collective narratives alive by passing them from one generation to another.

Exiled, humiliated, and dispossessed of their land, Palestinians resorted to writing as a collective response to the consistent effacement attempts of their history and as a tool to describe their losses and more often than not to expose the crimes of the outer group whom they perceived as enemies.

Art, poems, novels, and folk tales have therefore been their means of resistance, mourning and grieving. In fact, A quick generic analysis of the Palestinian literary heritage reveals that lots of the literary productions highlight the Palestinian- Israeli conflict and attempt to unveil the power dynamics that govern their relationship.

In the case of female writers, writing functions as a method to raise their voices and to share their perspective on the conflict and to "re-narrate Palestinian culture and identity in a way that reveals its multi-layered and polyphonic qualities" (Ball, 2012) in a society that is predominately patriarch, thus making writing, in this scenario, both a means of liberation from both the enemy and the disestablishment of male narrative and dominance over the creative expression of the Palestinian narrative.

In this sense, women in post-colonial literature in Palestine play a dual role of resistance against the oppression inflicted upon them by both patriarchy and occupation, thus juggling between 'nationalism and feminism' (Ball, 2012) which are both vital in maintaining the Palestinian identity against all forms of effacement. In other words, Palestinian female authors attempt to give agency both to females as writers and to their female characters who are reclaiming their autonomy in an attempt to uplift themselves from all kinds of colonial encounters.

Drawing on Edward Said's postcolonial theory in literature, I will map theoretical shifts between feminism and nationalism, resistance and submission and will try to answer the central question of the paper which revolves around how female Palestinian writers formulate and even 'reconfigure' resistance within their writing.

This paper helps shed light on the 'feminist' phase of Palestinian literature which is best described as "realistic, ideological and focused on the problem of the Palestinian woman, accentuating the connection that existed between the woman's problem and the national one" (Gottesfield, 2013). To achieve the purpose of the study, 
the research is divided into seven sections that at first help extrapolate the problem of the study, its significance, and some relevant literature followed by analysis and conclusions.

\section{Problem Statement}

Since literature is a reflection of society, its good values, and problems, there has been a colossal amount of research on literature concerning Palestinian political history and Palestinian resistance. This research trend, however, has not been conjoined with a parallel focus on the role of females in highlighting the injustices that women suffer from both as females under occupation and females in a patriarchal Middle Eastern society.

This lack of emphasis is to be compensated for by shifting towards a more gender-conscious analysis. Therefore, the problem of the study is limited to the following questions:

I. How does the nationalistic sentiment conflate with the feminist sentiment in the autobiography Sahron and my Mother in Law?

II. How does the existential dilemma of the colonized subjects affect the formation of their identity and their resistance?

\section{Significance}

This paper is a new venue in the sense that it seeks to shed light on how female Palestinian authors discursively manage their identities by highlighting through their writing two spheres that complement each other; the development of colonial discourse on one hand and the realities of political speech present in postcolonial environments on the other hand. Hence the researcher aims to capture interaction between the female characters in the narrative and their surrounding as well as that between the authors and their environment which will enable the analysis to focus not only upon the finished product but also to see the actual process of constructing that finished 'product/identity' in trying to reconceptualize the developmental practices in the colonies.

Against this, the importance of the research is seen in addressing the Palestinian cause and resistance conflating both nationalistic and feminist stimuli.

\section{Methodology}

To examine colonial discourse and answer the research questions above, this research paper relies on a descriptive, qualitative approach and focuses on the autobiography Sharon and my Mother in Law written by the Palestinian architect Saud Amiry in order to explore how collective memory can be shaped in postcolonial communities.

\section{Situating within Existing Literature}

\subsection{Postcolonial Literature}

Over recent years, an increase in academic interest has been seen in relation to postcolonial literature of the cultures affected by the imperial process. This rise in academic interest has run parallel to the increased awareness of the atrocities brought upon colonized countries and the hardships of displacement, refugeeism, migration, and exile that have come to play an integral part in the lives of individuals.

Many recent studies have taken concepts initially written about by Michel Foucault who made a connection between the production and the exercise of power (Foucault, 1998); power was no more seen as coercive, but rather pervasive as argued by Gaventa who proposes that Foucault's "work marks a radical departure from previous modes of conceiving power and cannot be easily integrated with previous ideas, as power is diffuse rather than concentrated, embodied and enacted rather than possessed, discursive rather than purely coercive, and constitutes agents rather than being deployed by them" $(2003,1)$.

Foucault's classic thoughts and ideas have been taken and adapted in the works of Edward Said who through his description of the orient's misconceptions or better yet assumptions has set the academic stage for revealing the basic concepts related to postcolonialism and has set for rejection of orientalism which is "a rejection of biological generalizations, cultural constructions, and racial and religious prejudices" (Sered, 1996), thusly giving voice to the voiceless and shifting the voice of 'subaltern' and downtrodden groups who have been traditionally marginalized and exploited which is an idea that has been extended and further explained by Spivak in her essay "Can the Subaltern Speak?".

Like Said, Spivak attempts to raise awareness related to the injustices inflicted upon those who are viewed as less powerful and tries to restore the voices that were lost and those who are still to this day silenced.

This combines such literature with that of deconstruction of colonial power and the Derridan concept of différance distinguishing its self through its focus on Palestinian context and Palestinian authors. 


\subsection{Autobiography as a Writing Strategy in Postcolonial Literature}

Autobiography has not always been recognized as a literary genre in mainstream literature. In fact, some critics reduced this genre to 'mere diary' (Lebdai, 2015). Recently however, the genre "developed its own codes and its own particularities, and now having its own theorists, critics and specialists" (Lebdai, 2015: 1).

What further distinguishes autobiographies is the fact that they are in most cases written by people who are not writers by profession. In this sense, they have become more than an autofication of a select people's narrative. They have become a method that 'nonwriters' can use to represent their life alongside with their 'quest for identity' (Lebdai, 2015: 2). This search for self-recognition is especially heightened in colonialized areas as "autobiography is [focused on as] a liberating genre... [through which they can] give voice to their selves and their cultural contexts through self-storytelling, autofiction or autobiography" (ibid).

For Palestinians, autobiographies serve as a means of documenting their ongoing struggle and preserving their collective memory. In this sense, we find Suad Amiry, a Palestinian architect living in Ramallah documenting her story and that of three million Palestinians living under occupation throughout two different periods; the first one spanning 1981 to 1995 and the second November 2001 to September 2002 and the autobiography which is eventually published is seen as "a form of therapy" (as cited in Hamzeh, 2006) for Amiry and as an "important historic testimony of a people's unwavering ability to continue their struggle for liberation" (ibid).

\subsection{Collective Memory in Palestinian Literature}

The term collective memory was first introduced in the 1920s by the sociologist Maurice Halbwachs (Halbwachs, 1980). According to Roediger and Abel (2015), collective memory refers to "recollection of events shared by a group" which has turned to narratives "that recover moments of colonial and communal trauma" (Ball, 2015:154) as the colonized people have to get back to the past to find a voice and identity (Barry, 1995). In this context, Williams and Chrisman (1993: 392) state that "the past no longer addresses us as a simple, factual 'past', since our relation to it, like the child's relation to the mother, is always-already after the break."

Colonial trauma has been and continues to be an integral part of the Palestinian literature and has become a marker of the Palestinian identity, thusly creating what Kahanoff $(2001,59)$ refers to as "intergenerational transmission of the trauma that affects everyone who is under the ethnic or national tent" making the understanding of colonial trauma central to any study of Palestinian literature.

\subsection{Feminism in Palestinian Literature}

Throughout the national resistance movement, writing was used as a medium to express resistance to colonialization. The creative expression, however, has until recently been vehemently dominated by male writers' narrative (Ball, 2015), thusly reducing females and their roles to "symbolic bearers of the collectivity's identity and honor" (Yuval-Davis, 1997:10). One reason behind this patriarch hegemony over cultural discourse is the long-held belief that feminism is a by-product of colonization and that it is at odds with nationalism and works to perpetuate western imperialism (Heng, 1997).

White (2013) contends that new paradigms for representing women in Palestine have been presented as the role of women has been reconfigured; females are no longer restricted to passive and sentimental mother figures, but rather central in both 'conflict management and post-conflict reconstruction.'

\section{Findings and Results}

\subsection{The First Question}

"How does the nationalistic sentiment conflate with the feminist sentiment in the autobiography Sahron and my Mother in Law?"

The autobiography serves as a historic testimony of the unwavering struggle under occupation and the sufferings of the citizens whose only fault is being born in a colonized country. In such circumstances a Palestinian is given no choice; politics becomes a centric part of everyday conversations and daily routine, especially during the incursion periods of 1981 to 1995 and November 2001 to September 2002 that Amiry describes in her autobiography.

Throughout the autobiography Amiry deliberately highlights the absurdities of life under Israeli occupation. What distinguishes this autobiography from others describing life under occupation is the fact that Amiry's role as a woman is augmented and she is given agency; Amiry is not a typical submissive, man-obeying woman, rather she is an architect, an entrepreneur -the founder and director of the RIWAQ Center for Architectural Conservation- , defies curfew, talks back at Israeli soldiers in airports and checkpoints, and climbs up walls trying to get to her mother in law as can be seen in this excerpt from the autobiography 
“...[I went to where my] ninety-one-year-old mother-in-law, Um Salim, lived, had no electricity, telephones or water, as I learned from her when I first saw her twelve days later. I felt angry and frustrated as I was waiting for an opportunity to go and check on Um Salim and Zakiyyeh, her helper. I wanted to try to reach them and see how they were doing.... as it turned out, my mother-in-law was anxiously waiting for me to appear to take her and Zakiyyeh away from their house, which was at the front line...I tried to find my way through an empty lot behind Eman's, just looking at the ground and hoping none of the Israeli soldiers would see me or shoot at me. I walked fast and fairly steadily. The few hundred feet felt more like a few hundred miles. I got to Eman's, climbed her garden wall and jumped. I walked through her garden and climbed another wall, this one higher."

In another encounter in the fourth entry "The Seven-Year Epic of My Identity 1981-1988" we see Saud ready "[a]fter seven years...to take control of [her] life" as she explodes at the Israeli Civil Administration officer demanding that he give her the long-awaited for hawiyyeh (ID).

In the sixth entry of the autobiography, Amiry and her husband Salim go on a shopping spree to stock supplies in anticipation of another turmoil in the area. On their way back home, a young male solider stops the car and asks Salim and Vera (Suad's friend) to step out of the car. Unable to reach the lever to flip forward the front seat, Suad is commanded to stay in the car. While Salim is being body-searched and emptying the shopping bags in the trunk, Suad "[is] contemplating confrontation strategies" and ends up staring the solider in the eye. Angered by Suad's action, the soldier demands her to stop; Suad, however, refuses to cease staring and defies both the solider and her husband who begs her to comply with the soldier's order. Eventually, Salim gets sent back to the car with a reprimand "mush 'aref trabi maratak (you don't even have the power to force your wife to behave)". Neither the solider nor Salim have the power to force Suad to act against her will. She has reclaimed her independence, nationalism, and feminism.

In these snapshots and episodes, we see Suad raising her voice against injustice, defying social norms and expectations; she shows us an example of a strong Palestinian female who helps women in reclaiming their own space as well as using literature as a means of revealing the oppression inflicted upon them, thusly reversing the traditional role of literature in legitimizing male dominance and perpetuating at a subconscious level women inferiority.

\subsection{The Second Question}

"How does the existential dilemma of the colonized subjects affect the formation of their identity and their resistance?"

The dichotomy between existence and resistance has always been at play in colonized countries. Colonized subjects are always at distress as they wish to lead 'normal' lives and to continue to exist which is usually contradicted with the imperial attempts to annihilate and to delegitimize the colonized rights of being. Amiry through the description of various encounters narrates quite humorously the absurdity of occupation which denied her access to an ID and granted a passport to her dog "I am the dog's driver. As you can see, she is from Jerusalem, and she cannot possibly drive the car or go to Jerusalem all by herself".

In another snapshot of the autobiography we see a Palestinian senior citizen 'Um Salim' (Amry's mother in law) refusing to leave her jewelry behind even though Amiry asserts to her that she will come back for them. Although that episode might not catch the reader's attention, but once the mother in law reminisce her journey of exile saying "that's what we said in 1948 when we left our house in Jaffa", the reader comes to an understanding of Um Salim's logic and how her identity came to be forged by the recurrent displacement and conflict.

Such episodes evoke a range of feelings that start as anger and frustration and turn to laughter and humor because "all it takes is a bit of humor" says Amiry.

\section{Conclusions}

In light of the analysis and the results of answering the research questions, the researcher concludes:

Females in Palestine have managed to reclaim their creative space and to defy male hegemony over the Palestinian narrative.

The colonized identity is affected and shaped by that of collective memory and their existence is always tied to the 'other' and their ability to balance powers of resistance and survival.

\section{Acknowledgments}

It is my great pleasure to thank my university (Palestine Technical University-Kadoorie) for all the encouragement and support to achieve my research. 


\section{References}

Ball, A. (2012). Palestinian Literature and Film in Postcolonial Feminist Perspective. Abingdon: Routledge. https://doi.org/10.4324/9780203098660

Barry, P. (2009). Beginning theory: An introduction to literary and cultural theory. Manchester, UK: Manchester University Press.

Between a Postcolonial Nation and Fantasies of the Feminine: The Contested Visions of Palestinian Cinema Ball A. Camera Obscura, 2008, 23(3), 1-35. https://doi.org/10.1215/02705346-2008-006

Chrisman, L., \& Williams, P. (1993). Colonial discourse and post-colonial theory: A reader. New York: Harvester Wheatsheaf.

Foucault, M. (1998). The History of Sexuality: The Will to Knowledge, London, Penguin.

Gaventa, J. (2003). Power after Lukes: a review of the literature, Brighton: Institute of Development Studies.

Gottesfield, D. (2013). Mirrors of Alienation: West Bank Palestinian Women's Literature after Oslo. Journal of Arabic and Islamic Studies, 13, 22-40. https://doi.org/10.5617/jais.4625

Halbwachs, M. (1980). The Collective Memory, Harper \& Raw translated by Didder, F. J. and Ditter, V. Y.

Hamzeh, M. (2006). Sharon and My Mother-in-Law: Ramallah Diaries. Journal of Palestine Studies, 36(1), 9092. https://doi.org/10.1525/jps.2006.36.1.90

Heng, G. (1997). A Great Way to Fly: Nationalism, the State, and the Varieties of Third-World Feminism, in Feminist Genealogies, Colonial Legacies, Democratic Futures. New York: Routledge.

Kahanoff, M. (2001). Collective Trauma, Recognition and Reconciliation in the Israeli-Palestinian Conflict. Group Analysis, 34 (1), 59-92. https://doi.org/10.1163/9789004355804_006

Lebdai, B. (2015). Autobiography as a Writing Strategy in Postcolonial Literature. Cambridge Scholars Publishing.

Roediger, H., \& Abel, M. (2015). Collective memory: a new arena of cognitive study. Trends in Cognitive Sciences, 19(7), 359-361. https://doi.org/10.1016/j.tics.2015.04.003

Said, E. (1993). Culture \& imperialism. London: The Random House Group Limited. Said, Edward W. (1979). Orientalism. New York: Vintage Books.

Sered, D. (1996). Orientalism. Postcolonial Studies at Emory pages. Retrieved from https://scholarblogs.emory.edu/postcolonialstudies/2014/06/21/orientalism/

White, B. (2013). Gender and Resistance in the Israeli-Palestinian Conflict: The Woman's Voice in the Literary Works of Sahar Khalifeh and David Grossman. The Ohio State University, United States.

Yuval-Davis, N. (1997). Gender and Nation. SAGE Publications Ltd.

\section{Copyrights}

Copyright for this article is retained by the author(s), with first publication rights granted to the journal.

This is an open-access article distributed under the terms and conditions of the Creative Commons Attribution license (http://creativecommons.org/licenses/by/4.0/). 